\title{
Analisis Regresi Logistik dengan Metode Penduga Bayes untuk Menentukan Faktor-Faktor Yang Berpengaruh Terhadap Kejadian Kanker Payudara (Studi Kasus: Pasien Kanker Payudara di Rumah sakit Dr. Wahidin Sudirohusodo)
}

\author{
Baiq Dian Meliza*, Muhammad Nadjib Bustan, Sudarmin \\ Program Studi Statistika, Fakultas Matematika dan Ilmu Pengetahuan Alam, Universitas Negeri Makassar, Indonesia
}

Keywords: Biner Logistic Regression, Bayes Method, Breast Cancer

\begin{abstract}
:
Logistic regression is an analysis statistics method to description the relations between dependent variable to have two category or more with one or more independent variable. This research purpose to explain some of the factor that effect birth weightin the Breast Cancer Patients "Dr. Wahidin Sudirohusodo Hospital" in 2017, To fulfill the goal to use logistic regression analysis using the Bayes method is parameter estimate method to unite likelihood and prior distribution. For exponential distribution. From this research, if using quantile value of $2,5 \%$ for parameter estimasi method by Bayes and the results obtained are the factors that significantly influence breast cancer incidence are the age of breast cancer patients, the location of breast cancer, chemotherapy, metastatic status and family status.
\end{abstract}

\section{Pendahuluan}

Kanker payudara adalah suatu penyakit dimana terjadi pertumbuhan berlebihan atau perkembangan tidak terkontrol dari sel-sel jaringan payudara. Kanker payudara dikenal sebagai salah satu kanker yang paling sering menyerang kaum wanita. Selain itu, kecendrungan peningkatan prevalensinya tidak dapat dihindari. Ditambah lagi kematian karena kanker payudara masih tinggi, oleh karena itu peneliti ingin mengambil kasus ini supaya wanita-wanita yang ada di Indonesia bisa lebih memperhatikan yang namanya kanker payudara, karena bisa dibayangkan bagaimana perasaan dan kehidupan seorang perempuan yang hidup tanpa payudara (Nadjib Bustan, 2015).

Pada penelitian ini akan dilakukan pengklasifikasian diagnosis keadaan pasien kanker payudara jinak dan ganas serta melakukan analisis faktor-faktor apa saja yang mempengaruhi kanker payudara menggunakan metode regresi logistik biner.

Model regresi logistik merupakan pemodelan statistik yang diterapkan untuk memodelkan variabel terikat yang bersifat kategori berdasarkan satu atau lebih variabel bebas. Model Regresi logistik sering digunakan dalam epidemiologi yaitu studi tentang pola terjadinya penyakit dan faktor-faktor yang mempengaruinya (Colleit, 1994).

Berdasarkan banyaknya pengkategorian variabel terikatnya, model regresi logistik dibedakan menjadi dua yaitu : model regresi logistik biner (dikotomus) dan model regresi logistik mutinomial (polikotumus). (Hosmer, 2000)

\footnotetext{
* Corresponding author.

E-mail address: baiqdianmeliza97@gmail.com
} 
Regresi logistik biner merupakan salah satu model regresi logistik yang bertujuan untuk mencari pola hubungan antara variabel yang bersifat biner dengan satu atau lebih varibel bebas. Hasil dari variabel terikat hanya ada dua kemungkinan, yaitu "ya" (diberi kode 1) dan "tidak" (diberi kode 0).

Metode pendugaan parameter yang umum digunakan pada regresi logistik biner adalah Metode Maksimum Likelihood, Akan tetapi pada penelitian ini kurang tepat apabila menggunakan Metode Maksimum Likelihood dalam pendugaan parameter, hal ini disebabkan oleh ukuran sampel yang kecil, apabila metode Maksimum Likelihood tetap digunakan maka hasil dari pendugaan parameter akan bias. Selain itu, standard erors yang dihasilkan mungkin tidak tepat dan mengarah pada selang kepercayaan maupun statistik uji yang salah, ukuran sampel yang kecil yaitu kurang dari 30 sampel (Scheaffer, 1990).

Alternatif untuk mengatasi masalah tersebut adalah menggunakan metode pendugaan parameter lain yaitu metode Bayes, metode Bayes merupakan metode pendugaan parameter yang menggabungkan informasi awal yang disebut sebagai distribusi prior, dan hasilnya dinyatakan sebagai distribusi posterior.

Dasar dari metode Bayes adalah probabilitas bersyarat, sehingga untuk melakukan pendugaan diperlukan sebuah informasi awal dari parameter yang disebut dengan distribusi prior. Distribusi prior dapat dinotasikan dengan $\pi(\boldsymbol{\theta})$, yang mana adalah $\boldsymbol{\theta}$ parameter dari distribusi sampel.

Jika dibandingkan antara penduga Parameter Maksimum Likelihood dengan Metode Bayes dilihat dari ragam dan Kuadrat Terkecil Galat dari Estimator Bayes lebih kecil dari pada estimator Maksimum Likelihood, ini dapat dikatakan sebagai sebuah keunggulan tersendiri dari Estimator Bayes bahwa Estimator Bayes menghasilkan estimator yang baik untuk parameter jika kuadrat terkecil galat dan ragam yang menjadi ukuran kebaikannya.

Metode Bayes sebelumnya telah diterapkan oleh (Olivia, 2012) dalam artikelnya "Pemodelan Regresi logistik Mutinomial menggunakan Metode Bayes, dalam penelitiannya tersebut penulis membentuk model regresi logistik Multinomial dengan menggunakan Metode Bayes sebagai metode pendugaan parameter.

Sesuai uraian diatas maka peneliti telah mengkaji dan melakukan penelitian yang berjudul "Analisis Regresi Logistik dengan Metode Penduga Bayes untuk Menentukan Faktor-Faktor Yang Berpengaruh Terhadap Kejadian Kanker Payudara (Studi Kasus: Pasien Kanker Payudara di Rumah sakit Dr. Wahidin Sudirohusodo)

\section{Metode Penelitian}

Adapun teknik analisis data yang digunakan dalam penelitian ini adalah:

1. Menyiapkan data yang akan digunakan dalam penelitian

2. Analisis deskriptif terhadap peubah penjelas serta peubah respon

3. Pendugaan parameter model

Pada tahap ini penaksiran parameter terhadap model regresi logistik biner menggunakan pendekatan Bayesian .

a. Menentukan fungsi likelihood

b. Menentukan distribusi prior

c. Menentukan distribusi posterior

4. Keakuratan model

$$
\pi(x)=\frac{\exp \left(\beta_{0}+\beta_{1} X_{1}+\beta_{2} x_{2}+\beta_{3} x_{3}+\beta_{4} x_{4}+\beta_{5} X_{5}\right)}{1+\exp \left(\beta_{0}+\beta_{1} X_{1}+\beta_{2} x_{2}+\beta_{3} x_{3}+\beta_{4} x_{4}+\beta_{5} X_{5}\right)}
$$

5. Kesimpulan 


\section{Hasil dan Pembahasan}

\subsection{Hasil Penelitian}

\subsubsection{Kajian Matematis dari Estimasi Parameter Metode Bayes}

Dasar dari metode Bayes adalah probabilitas bersyarat, sehingga untuk melakukan estimasi diperlukan sebuah informasi awal dari parameter yang disebut dengan distribusi prior. Distribusi prior dapat dinotasikan dengan $\pi(\theta)$, yang mana $\theta$ adalah parameter dari distribusi sampel. Salah satu distribusi prior adalah distribusi prior Jeffrey yaitu $\pi(\theta) \alpha \sqrt{I(} \theta)$, dimana

$$
I(\theta)=-n E\left(\frac{\partial^{2} \ln f(x, \theta}{\partial \theta^{2}}\right)
$$

Dalam aplikasinya, distribusi prior Jeffrey diperluas menjadi perluasan distribusi prior Jeffrey yaitu:

Untuk semua $c \in R^{+}$

$$
\pi(\theta) \infty[I(\theta)]^{c}
$$

Sehingga perluasan distribusi prior Jeffrey untuk Distribusi Eksponensial yaitu:

$$
\pi(\theta)=k \frac{n^{c}}{\theta^{2 c}}
$$

Dengan $k$ adalah konstanta, $c \in R^{+}$dan $\mathrm{n}$ adalah jumlah sampel.

Distribusi prior kemudian dikombinasi dengan distribusi sampel yang akan menghasilkan distribusi baru yaitu distribusi posterior. Distribusi posterior diperoleh dengan cara membagi fungsi kepadatan bersama dengan fungsi marginal, untuk menghasilkan fungsi kepadatan bersama dan funsi marginal dilakukan dengan cara berikut :

Fungsi kepadatan bersama dari $\left(x_{1}, \ldots, x_{n}, \theta\right)$ yaitu:

Fungsi Marginal dari $\left(x_{1}, \ldots, x_{n}\right)$ yaitu :

$$
\begin{aligned}
& H\left(x_{1}, \ldots, x_{n}\right)=L\left(X_{1} \mid \theta\right) \pi(\theta) \\
& =\frac{k n^{c}}{\theta n+2 c} e-\frac{1}{\theta} \sum_{i=1}^{n} x i
\end{aligned}
$$

$$
\begin{gathered}
P\left(x_{1}, \ldots, x_{n}\right)=\int_{0}^{\infty} H\left(x_{1}, \ldots, x_{n}, \theta\right) d \theta P\left(x_{1}, \ldots, x_{n}\right)=\int_{0}^{\infty} \frac{k n^{c}}{\theta n+2 c} e-\frac{1}{\theta} \sum_{i=1}^{n} x i d \theta \\
=\frac{k n^{c}(n+2 c-2) !}{\left(\sum_{i=1}^{n} x_{i}\right)^{n+2 c-1}}
\end{gathered}
$$

Dari persamaan (3.1) dan persamaan (3.2) distribusi posterior dapat ditulis sebagai berikut:

$$
\pi\left(\theta \mid x_{1}, \ldots, x_{n}\right)=\frac{H\left(\theta \mid x_{1}, \ldots, x_{n}, \theta\right)}{\int_{0}^{\infty} H\left(\theta \mid x_{1}, \ldots, x_{n}, \theta\right)}=\frac{\theta^{-n-2 c} e^{\frac{1}{\theta}} \sum_{i=1}^{n} x_{1}}{\left(\sum_{i=1}^{n} x_{i}\right)^{1-n-2 c}(n+2 c-2) !} d \theta
$$

Estimasi Bayes adalah rata-rata dari distribusi posterior

$$
\begin{aligned}
E(\theta) & =\int_{0}^{\infty} \theta \pi\left(\theta \mid x_{1}, \ldots, x_{n}\right) d \theta \\
= & \int_{0}^{\infty} \theta \frac{\theta^{-n-2 c} e^{\frac{1}{\theta}} \sum_{i=1}^{n} x_{1}}{\left(\sum_{i=1}^{n} x_{i}\right)^{1-n-2 c}(n+2 c-2) !} d \theta \\
& =\frac{1}{\left(\sum_{i=1}^{n} x_{i}\right)^{1-n-2 c}(n+2 c-2) !}\left(\frac{(n+2 c-3) !}{\left(\sum_{i=1}^{n} x_{i}\right)^{n+2 c-2}}\right)
\end{aligned}
$$


$=\frac{\sum_{i=1}^{n} x_{i}}{n+2 c-2}$

Dengan demikian penduga Bayes bagi $\theta$ adalah $\frac{1}{n+2 c-2} \sum_{i=1}^{n} x_{i}$

Penduga yang diperoleh menggunakan metode Bayes dengan simulasi data dilakukan dengan membangkitkan berbagai jenis kondisi data yang melibatkan nilai $\theta$ serta ukuran sampel yaitu $n=45$ kemudian dilakukan perulangan sebanyak 10.000 kali setiap kombinasi $\theta \operatorname{dan} n$, data yang diperoleh tersebut dianalisis untuk menduga parameter $\theta$, penduga parameter dengan metode Bayes dengan menggunakan perluasan distribusi prior Jeffrey yang melibatkan beberapa nilai konstanta Jeffrey yaitu: $c=0,1$ dan 0,3 .

\subsubsection{Analisis Statistika Deskriptif}

Data dalam penelitian ini diperoleh dari Rumah Sakit Dr.Wahidin Sudirohusodo dengan jumlah data sebanyak 45 data kategori kanker payudara .

Berdasarkan data yang diperoleh dari 45 data kanker payudara, 15 diantaranya yang terkena kanker payudara ganas dan 30 kanker payudara jinak. Pada bagian analisis deskriptif peubah yang digunakan dalam penelitian dalam pemodelan faktor-faktor yang berpengaruh terhadap pasien kanker payudara. Dapat dilihat pada Tabel 1 mengenai persentase peubah kanker payudara yang digunakan dalam penelitian.

Tabel 3.1 Frekuensi Peubah Kanker Payudara

\begin{tabular}{lll}
\hline Peubah & Frekuensi & $\begin{array}{l}\text { Persentase } \\
(\%)\end{array}$ \\
\hline Y (Jenis Keganasan) & & \\
$\quad$ Ganas & 29 & 64,44 \\
$\quad$ Jinak & 16 & 35,56 \\
X $_{1}$ (Usia Pasien) & & \\
$\quad>45$ tahun & 30 & 66,67 \\
$\quad \leq 45$ tahun & 15 & 33,33 \\
X $_{2}$ (Letak Kanker) & & \\
$\quad$ Kiri & 20 & 44,44 \\
$\quad$ Kanan & 25 & 55,56 \\
$X_{3}$ (Kemoterapi) & & \\
$\quad$ Tidak & 20 & 44,44 \\
$\quad$ Ya & 25 & 55,56 \\
$X_{4}$ (Status Metastase) & & \\
$\quad$ Ya & 35 & 77,78 \\
$\quad$ Tidak & 10 & 22,22 \\
$X_{5}$ (Status pernikahan) & & \\
$\quad$ Belum Menikah & 10 & 22,22 \\
$\quad$ Menikah & 35 & 77,78 \\
\hline
\end{tabular}

a. Jenis Keganasan

Pada penilitian ini, Berdasarkan pada Tabel 1 jumlah data yang digunakan adalah sebanyak 45 penderita kanker payudara dengan kategori jenis keganasan yakni 26 orang penderita kanker payudara ganas dan 19 orang penderita kanker payudara jinak. Gambar 1 diperlihatkan bahwa presentase penderita yang memiliki jenis kanker payudara ganas yaitu sebesar 25 pasien atau 64,44\%. sedangkan presentase untuk penderita yang memiliki jenis kanker payudara jinak yaitu sebesar 18 pasien atau 35,56\% Ini menunjukkan bahwa penderita kanker payudara ganas lebih tinggi dibanding dengan penderita kanker payudara jinak. 


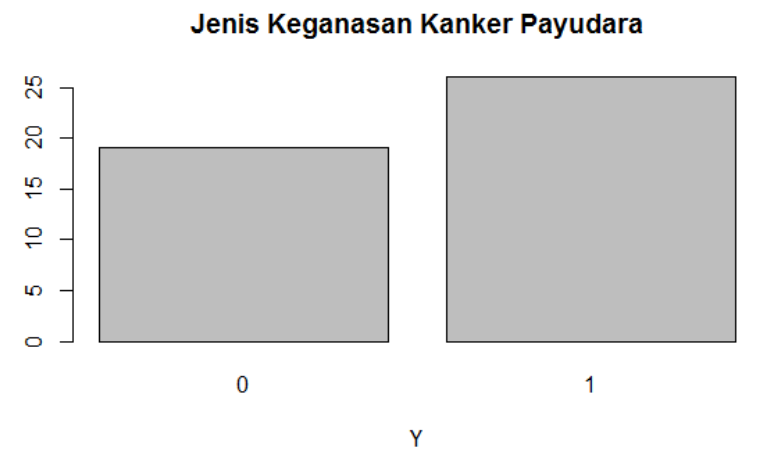

b. Usia

Gambar 1 Jenis Keganasan Kanker Payudara

Usia menjadi salah satu faktor seorang terkena kanker payudara yang sudah memasuki masa reproduksi. Berdasarkan Tabel 1 diperlihatkan rata-rata usia penderita kanker payudara yakni usia diatas 45 tahun.

Kategori Usia

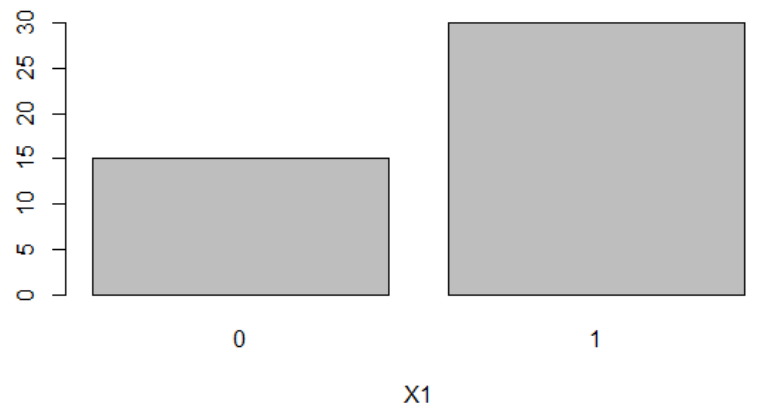

Gambar 2 Usia Penderita Kanker Payudara

c. Letak Kanker

Berdasarkan Gambar 3 Letak kanker yang dimaksud dalam penelitian ini adalah penderita kanker payudara sebesar 25 orang terletak pada payudara kanan dan 20 letak kanker payudara berada disebelah kiri.

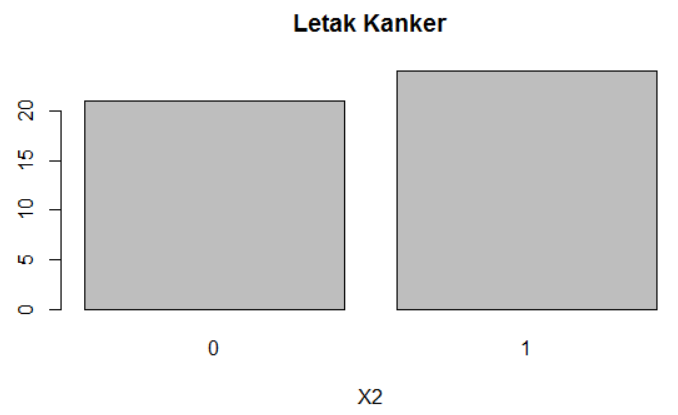

d. Kemoterapi

Gambar 3 Letak Kanker Payudara

Penderita kanker payudara akan mendapatkan tindakan terapi dari dokter, tindakan yang dilakukan adalah kemoterapi. Berdasarkan gambar 4 diperoleh bahwa 25 orang dari penderita kanker payudara melakukan kemoterapi sementara 20 orang penderita lainnya tidak melakukan kemoterapi. 


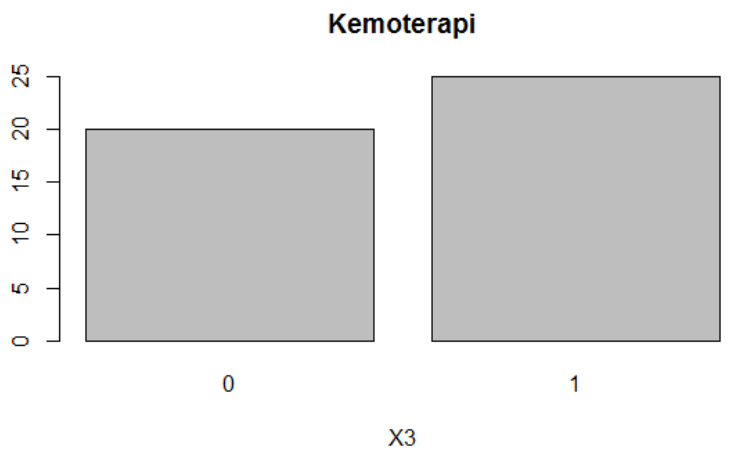

e. Status Metastase

Gambar 4 Kemoterapi Kanker Payudara

Metastase adalah kondisi dimana kanker sudah menyebar dari tempat pertama kali kanker itu tumbuh. Berdasarkan gambar 5 jenis kanker payudara ganas penderita kanker payudara sebesar 10 rang tidak mengalami metastase, sedangkan 35 orang mengalami metastase dimana jaringan kanker telah menyebar ke tubuh lainnya

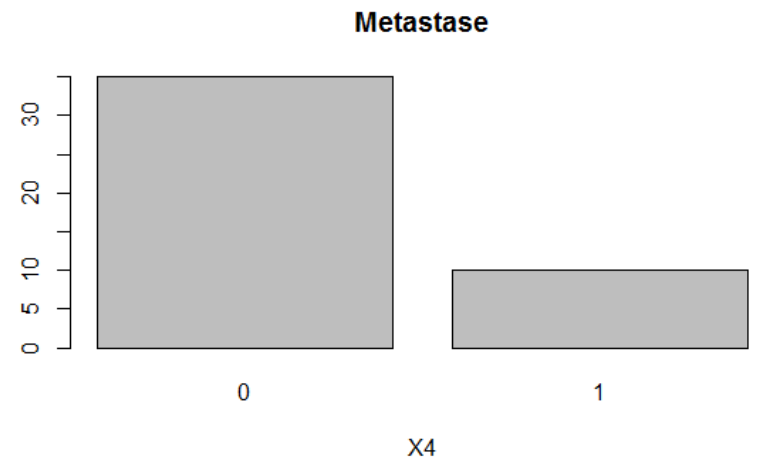

f. Status pernikahan

Gambar 5 Status Metastase Kanker Payudara

Berdasarkan pada Gambar 6 diperoleh bahwa 35 penderita kanker payudara adalah belum menikah. Sementara 10 lainnya penderita tidak mengalami kanker payudara yakni sudah menikah.

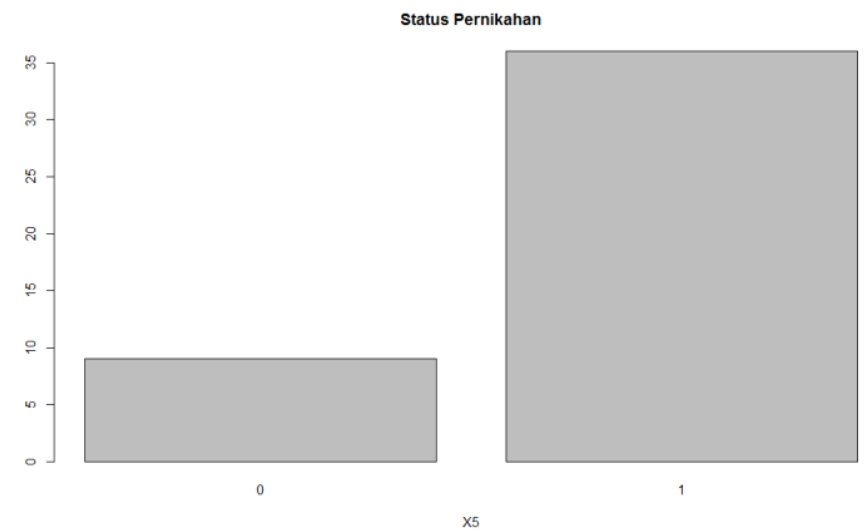

Gambar 6 Status Keluarga Kanker Payudara 


\subsubsection{Pemilihan Model Regresi Logistik Terbaik}

Untuk mendapatkan model yang terbaik terlebih dahulu mengestimasi parameter dengan menggunakan software $\mathrm{R}$, pada Iterasi 1001: 11000 dengan thining interval 1 memberikan hasil yang sudah konvergen. Berikut gambar plot posterior:

Adapun nilai estimasi parameter yang didapat dengan menggunakan metode Bayes dengan nilai kuantil ke 2,5\% dan kuantil 97,5\% adalah sebagai berikut:

Tabel 2 Nilai Estimasi Parameter

\begin{tabular}{lcccl}
\hline \multicolumn{1}{c}{ Parameter } & Mean & $\begin{array}{c}2,5 \% \\
\text { kuantil }\end{array}$ & $\begin{array}{c}97,5 \% \\
\text { kuantil }\end{array}$ & $\begin{array}{c}\text { Odds } \\
\text { Rasio }\end{array}$ \\
\hline Penderita Kanker & $-6,347$ & $-11,3767$ & $-2,739$ & \\
Usia Pasien $\left(\mathrm{X}_{1}\right)$ & $-3,702$ & $-6,0036$ & $-1,845$ & $-2,155$ \\
Letak Kanker $\left(\mathrm{X}_{2}\right)$ & 4,262 & 2,0212 & 7,067 & 2,790 \\
Kemoterapi $\left(\mathrm{X}_{3}\right)$ & 7,253 & 4,2116 & 11,207 & 5,547 \\
Status Metastase $\left(\mathrm{X}_{4}\right)$ & 14,848 & 5,4444 & 24,264 & 21,301 \\
Status pernikahan $\left(\mathrm{X}_{5}\right)$ & 3,197 & 0,9489 & 5,845 & 1,898 \\
\hline
\end{tabular}

Pengujian hipotesis terhadap parameter regresi dilakukan dengan pendekatan interval konvidensi $97,5 \%$ dari masingmasing parameter. Hal ini dikarenakan distribusi posterior tidak diketahui dengan pasti, interval konvidensi $975 \%$ dihitung dengan batas bawah yaitu kuantil 2,5\% dan batas atasnya adalah 97,5\%. Parameter dinyatakan signifikan jika interval konvidensi 97,5\% parameter tidak memuat nilai nol, parameter yang signifikan menunjukkan variabel bebas berpengaruh terhadap variabel terikat dan parameter yang tidak signifikan menyatakan variabel bebas tidak berpengaruh terhadap variabel terikat,

Tabel 2 menjelaskan bahwa variabel usia pasien $\left(X_{1}\right)$, peubah letak kanker payudara $\left(X_{2}\right)$, peubah kemoterapi $\left(X_{3}\right)$, peubah metastase $\left(X_{4}\right)$, status pernikahan $\left(X_{5}\right)$, memiliki masing-masing nilai yang tidak memuat nilai 0 , maka dapat disimpulkan bahwa peubah penjelas yang berpengaruh nyata terhadap jenis keganasan kanker terhadap pasien kanker adalah variabel usia pasien, letak kanker payudara, kemoterapi, metastase dan status pernikahan.

a. Pengujian (kuantil $2,5 \%$ dan $97,5 \%$ )

1. Faktor Usia

Untuk menentukan signifikan atau tidaknya pengaruh variabel usia terhadap kanker payudara, maka diperlu dilakukan pengujian hipotesis berikut ini:

$H_{0}$ : variabel usia tidak berpengaruh signifikan terhadap kanker payudara

$H_{1}$ : variabel usia berpengaruh signifikan terhadap kanker payudara

Berdasarkan tabel 2 diperoleh nilai kuantil ke 2,5\% adalah -6,0036 dan 97,5\% adalah $-1,845$ karena nilai kuantil ke 2,5\% dan kuantil ke 97,5\% tidak memuat nilai 0 maka $H_{0}$ ditolak, sehingga dapat disimpulkan bahwa faktor usia berpengaruh signifikan terhadap kejadian kanker payudara.

2. Faktor letak kanker payudara

Untuk menentukan signifikan atau tidaknya pengaruh variabel letak kanker payudara terhadap kanker payudara, maka diperlu dilakukan pengujian hipotesis berikut ini:

$H_{0}$ : variabel letak kanker payudara tidak berpengaruh signifikan terhadap kanker payudara

$H_{1}$ : variabel letak kanker payudara berpengaruh signifikan terhadap kanker payudara 
Berdasarkan tabel 2 diperoleh nilai kuantil ke 2,5\% adalah 2,0212 dan 97,5\% adalah 7,067 karena nilai kuantil ke 2,5\% dan kuantil ke 97,5\% tidak memuat nilai 0 maka $H_{0}$ ditolak, sehingga dapat disimpulkan bahwa faktor letak kanker payudara berpengaruh signifikan terhadap kejadian kanker payudara.

3. Faktor kemoterapi

Untuk menentukan signifikan atau tidaknya pengaruh variabel kemoterapi terhadap kanker payudara, maka diperlu dilakukan pengujian hipotesis berikut ini:

$H_{0}$ : variabel kemoterapi tidak berpengaruh signifikan terhadap kanker payudara

$H_{1}$ : variabel kemoterapi berpengaruh signifikan terhadap kanker payudara

Berdasarkan tabel 2 diperoleh nilai kuantil ke 2,5\% adalah 4,2116 dan 97,5\% adalah 11,207 karena nilai kuantil ke 2,5\% dan kuantil ke 97,5\% tidak memuat nilai 0 maka $H_{0}$ ditolak, sehingga dapat disimpulkan bahwa faktor kemoterapi berpengaruh signifikan terhadap kejadian kanker payudara.

4. Faktor metastase

Untuk menentukan signifikan atau tidaknya pengaruh variabel metastase terhadap kanker payudara, maka diperlu dilakukan pengujian hipotesis berikut ini:

$H_{0}$ : variabel metastase tidak berpengaruh signifikan terhadap kanker payudara

$H_{1}$ : variabel metastase berpengaruh signifikan terhadap kanker payudara

Berdasarkan tabel 3.2 diperoleh nilai kuantil ke 2,5\% adalah 5,4444 dan 97,5\% adalah 24,264 karena nilai kuantil ke 2,5\% dan kuantil ke 97,5\% tidak memuat nilai 0 maka $H_{0}$ ditolak, sehingga dapat disimpulkan bahwa faktor metastase berpengaruh signifikan terhadap kejadian kanker payudara.

5. Faktor status pernikahan

Untuk menentukan signifikan atau tidaknya pengaruh variabel status pernikahan terhadap kanker payudara, maka diperlu dilakukan pengujian hipotesis berikut ini:

$H_{0}$ : variabel status pernikahan tidak berpengaruh signifikan terhadap kanker payudara

$H_{1}$ : variabel status pernikahan berpengaruh signifikan terhadap kanker payudara

Berdasarkan tabel 4.2 diperoleh nilai kuantil ke 2,5\% adalah 0,9489 dan 97,5\% adalah 5,845karena nilai kuantil ke 2,5\% dan kuantil ke 97,5\% tidak memuat nilai 0 maka $H_{0}$ diterima, sehingga dapat disimpulkan bahwa faktor status pernikahan berpengaruh signifikan terhadap kejadian kanker payudara.

Dari pengujian yang telah dilakukan dengan menggunakan nilai kuantil ke 2,5\% dan kuantil 97,5\% tampak variabel yang berpengaruh adalah faktor usia,letak kanker payudara, kemoterapi dan metastase dan status pernikahan sedangkan variabel yang tidak berpengaruh tidak ada. Sehingga model yang terbentuk adalah sebagai berikut:

$$
\pi(x)=\frac{e^{\left.(-6,347)+(-3,702)\left(x_{1}\right)+4,262\left(x_{2}\right)+7,253\left(x_{3}\right)+14,848\left(x_{4}\right)+3,197\left(x_{5}\right)\right)}}{1+e^{\left.(-6,347)+(-3,702)\left(x_{1}\right)+4,262\left(x_{2}\right)+7,253\left(x_{3}\right)+14,848\left(x_{4}\right)+3,197\left(x_{5}\right)\right)}}
$$

\subsection{Pembahasan}

Dari hasil menggunakan pengujian parameter dengan menggunakan nilai kuantil 2,5\% dan 97,5\% terdapat beberapa faktor yang berpengaruh secara signifikan terhadap kejadian kanker payudara adapun model yang terbentuk adalah:

$$
\pi(x)=\frac{e^{\left.(-6,347)+(-3,702)\left(x_{1}\right)+4,262\left(x_{2}\right)+7,253\left(x_{3}\right)+14,848\left(x_{4}\right)+3,197\left(x_{5}\right)\right)}}{1+e^{\left.(-6,347)+(-3,702)\left(x_{1}\right)+4,262\left(x_{2}\right)+7,253\left(x_{3}\right)+14,848\left(x_{4}\right)+3,197\left(x_{5}\right)\right)}}
$$

Berdasarkan nilai Odds rasio maka dapat dijelaskan bahwa:

1. Usia 
Hubungan antara persentase usia $\left(\mathrm{X}_{1}\right)$ dengan jenis keganasan kanker adalah positif dengan nilai odds rasio sebesar $-2,15$ yang artinya pasien penderita kanker payudara yang berusia diatas 40 tahun memiliki peluang untuk terkena kanker payudara ganas sebesar 2,15 kali lebih besar pada pasien yang berusia dibawah 40 tahun.

2. Letak Kanker Payudara

Hubungan antara persentase kemoterapi $\left(\mathrm{X}_{2}\right)$ dengan jenis keganasan kanker adalah positif dengan nilai odds rasio sebesar 2,79 yang artinya pasien penderita kanker payudara yang letak kanker payudara sebelah kanan memiliki peluang untuk terkena kanker payudara ganas sebesar 2,79 kali lebih besar pada pasien yang letak kanker payudaranya sebelah kiri.

3. Kemoterapi

Hubungan antara persentase kemoterapi $\left(\mathrm{X}_{3}\right)$ dengan jenis keganasan kanker adalah negatif dengan nilai odds rasio sebesar 5,547 yang artinya pasien penderita kanker payudara yang tidak kemoterapi memiliki peluang untuk terkena kanker payudara ganas sebesar 5,547 kali lebih besar pada pasien yang kemoterapi.

4. Status Metastase

Hubungan antara metastase $\left(\mathrm{X}_{4}\right)$ dengan jenis keganasan kanker adalah positif, dengan nilai odds rasio sebesar 21,3 yang menjelaskan bahwa pasien penderita kanker payudara yang telah metastase memiliki peluang terkena kanker payudara ganas sebesar 21,3 kali lebih besar dari pada pasien yang belum metastase.

5. Status Pernikahan

Hubungan antara Status pernikahan $\left(\mathrm{X}_{5}\right)$ dengan jenis keganasan kanker adalah positif, dengan nilai odds rasio sebesar 1,89 yang menjelaskan bahwa pasien penderita kanker payudara yang belum berstatus pernikahan memiliki peluang terkena kanker payudara ganas sebesar 1,89 kali lebih besar dari pada pasien yang sudah menikah.

Metode Bayes adalah metode untuk mengestimasi parameter-parameter model regresi dengan menggunakan interpretasi probabilitas secara subjektif, metode ini menggabungkan informasi dari data sampel dengan informasi lain yang telah tersedia sebelumnya (prior). Sedangkan metode maximum likelihood adalah salah satu metode untuk mengestimasi parameter model regresi, metode ini hanya mendasarkan inferensinya pada informasi data sampel dan metode tersebut pada dasarnya menafsirkan probabilitas sebagai frekuensi relatif. Jika distribusi populasi tidak diketahui maka metode ini tidak dapat dilakukan.

Uji kesesuaian model regresi logistik digunakan untuk mengetahui apakah model sesuai atau tidak terdapat perbedaan yang nyata antara hasil observasi dengan prediksi model, pada uji ini statistik uji yang digunakan adalah uji Hosmer dan Lemeshow seperti yang ditunjukkan pada Tabel 3.

Tabel 3 Hasil Uji Kesesuaian Model

\begin{tabular}{ccc}
\hline Chi-Square & $d f$ & $p$-value \\
\hline 0,95 & 3 & 0,8135 \\
\hline
\end{tabular}

Nilai Chi-Square pada tabel 3 yang diperoleh sebesar 0,95 dan $p$-value $=0.8135$. Dapat diartikan bahwa gagal tolak $\mathrm{H}_{0}$ karena $p$-value $>\alpha$ dengan $\alpha=5 \%$. Maka dapat disimpulkan bahwa model sesuai atau tidak terdapat perbedaan yang nyata antara observasi dengan prediksi model.

\section{Kesimpulan}

Berdasarkan dari hasil penelitian yang telah dilakukan, maka dapat disimpulkan bahwa:

1. Estimasi parameter metode bayes dengan menggunakan perluasan distribusi prior :

$$
\frac{1}{n+2 c-2} \sum_{i=1}^{n} x i
$$

Penduga yang diperoleh menggunakan metode Bayes dengan simulasi data dilakukan dengan membangkitkan berbagai jenis kondisi data yang melibatkan nilai $\theta$ serta ukuran sampel yaitu $n=45$ kemudian dilakukan perulangan sebanyak 10.000 kali setiap kombinasi $\theta$ dan $n$, data yang diperoleh tersebut dianalisis untuk 
menduga parameter $\theta$, penduga parameter dengan metode Bayes dengan menggunakan perluasan distribusi prior Jeffrey yang melibatkan beberapa nilai konstanta Jeffrey yaitu: $c=0,1$ dan 0,3 .

2. Berdasarkan analisis yang telah dilakukan nilai kuantil $2,5 \%$ dan kuantil $97,5 \%$ didapatkan bahwa ada beberapa faktor yang signifikan berpengaruh terhadap kejadian kanker payudara yaitu faktor usia, letak kanker payudara, kemoterapi, status metastase dan status pernikahan. Model terbaik yang terbentuk untuk faktor-faktor yang mempengaruhi jenis keganasan kanker payudara :

$$
\pi(x)=\frac{e^{\left.(-6,347)+(-3,702)\left(x_{1}\right)+4,262\left(x_{2}\right)+7,253\left(x_{3}\right)+14,848\left(x_{4}\right)+3,197\left(x_{5}\right)\right)}}{1+e^{\left.(-6,347)+(-3,702)\left(x_{1}\right)+4,262\left(x_{2}\right)+7,253\left(x_{3}\right)+14,848\left(x_{4}\right)+3,197\left(x_{5}\right)\right)}}
$$

Disimpulkan bahwa peubah penjelas yang berpengaruh nyata terhadap jenis keganasan kanker terhadap pasien penderita kanker payudara adalah semua faktor peubah penjelas signifikan dan faktor yang signifikan adalah sebagai berikut, persentase Usia $\left(\mathrm{X}_{1}\right)$, Letak kanker Payudara $\left(\mathrm{X}_{2}\right)$, kemoterapi kanker payudara $\left(\mathrm{X}_{3}\right)$, persentase metastase paseien kanker payudara $\left(\mathrm{X}_{4}\right)$ dan status pernikahan $\left(\mathrm{X}_{5}\right)$.

\section{References}

Agresti, A. (1990). Categorical Data Analysis. New York: John Willey \& Sons.

Association Cancer Society. (2013). Breast Cancer. Diakses 20 Agustus 2018. www.cancer.org/

Box, G.E.P dan Tiao, G.C (1973). Bayesian Inference in Statistical Analysis. Addision -Wesley Publishing Company, Inc: Philippines.

Bain, L.J dan Engelhardt, M. (1992). Introduction to Probability and Mathematical Statistics Second Edition. Duxbury Press: California.

Bustan, M.N. (2015). Manajemen Penegendalian Penyakit Tidak Menular. Jakarta: Rineka Cipta.

Colleit. (1994). Modeling Survival Data In Medical Research. London: Chaprnan And Hall.

Gelman, A., Carlin, J., Stem, H., \& Rubin, D. (1995). Bayesian data analysis. London: Chapman and Hall.

Gruendemann, B.J., \& Fersebner, B. (2005). Buku Ajar Keperawatan Perioperatif, vol 2 Paraktik (Terjemahan). Jakarta:EGC

Hosmer, D. A. (2000). Applied Logistic Regression Second Edition. New York: John Wiley And Son.

Indrati, Rini. (2005). Faktor Faktor Risiko yang Berpengaruh Terhadap Kejadian Kanker Payudara Wanita [Tesis]. Semarang: Universitas Diponegoro

Ntzoufraz, I.2009. Bayesian Modelling Using WinBUGS. John Wiley \& Sons, Inc: Ney Jersey.

Olivia, (2012). Pemodelan Regresi Logistik Mutinomial Menggunakan Metode Bayes (Studi kasus pada Pasien Penderita Penyakit Tuberkolosis Di Rumah Sakit Islam Universitas Islam Malang ). Jurnal : Matematika FMIPA Universitas Brawijaya.

Scheaffer, R. M. (1990). Elementary Survey Sampling Fourth Edition. Boston: PWS-KENT.

Subanar. 2013. Inferensi Bayesian. 10. Karunika Universitas Terbuka: Jakarta.

Tiro, M. A. (2004). Analisis Regresi Dengan Data Kategori. Edisi kedua. Makassar: Andira Publisher.

Tim Cancer Helps. (2010). Stop Kanker. Jakarta: PT Agro Media Pustaka 